\title{
Clinical Study of some Biochemical Parameters in Serum of Women Undergoing Uterine Removal
}

\author{
Raghad A. Hammo \\ Department of Chemistry / College of Science / University of Mosul
}

(Received 11/11/2018; Accepted 22 / 1 / 2019)

\begin{abstract}
The present research includes a clinical study of estrogen hormone and ferritin protein, cholesterol, and some levels of mineral, such as calcium and phosphorus in the serum of women who have undergone uterine removal. The results showed a significant decrease in the estrogen hormone level of serum for women who have undergone uterine removal $(50.3 \mathrm{Pg} / \mathrm{ml})$, in comparison with healthy women $(138.65 \mathrm{Pg} / \mathrm{ml})$ at a probability level of $\mathrm{P} \leq 0.05$. The study also showed a significant increase of ferritin protein level of women who have undergone uterine removal $(64.35 \mathrm{mg} / \mathrm{dl})$ when compared with healthy women $(52.10 \mathrm{mg} / \mathrm{dl})$ at probability level of $\mathrm{P} \leq 0.05$, with a significant increase in the cholesterol level in serum of women who have undergone uterine removal $(7.643 \mathrm{mmol} / \mathrm{L})$, in comparison with healthy women $(4.525 \mathrm{mmol} / \mathrm{L})$ at a probability level of $\mathrm{P} \leq 0.05$. The investigation also discussed the effect of some minerals, like calcium and phosphorous on the serum of women who have undergone uterine removal, and it found significant decrease in calcium level of women who have undergone uterine removal while compared with healthy women $(1.86),(2.41) \mathrm{mmol} / \mathrm{L}$ respectively at probability level $(\mathrm{P} \leq 0.05)$, while present slight increase in phosphorous level compared with healthy women(3.95), (3.731) $\mathrm{mmol} / \mathrm{L}$ respectively.
\end{abstract}

Keywords: Estrogen Hormon, Ferittin, Cholesterol, Calicum, Phosphorous.

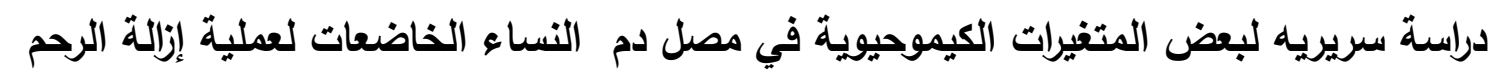

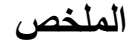

$$
\begin{aligned}
& \text { تضمن البحث دراسة هرمون الاستروجين وبروتين الفريتنين ومستوى الكولسترول وبعض المعادن كالكالسيوم والفسفور في } \\
& \text { مصل دم النساء مستأصلات الرحم. أظهرت النتائج انخفاضا معنويا في مستوى هرمون الاستروجين للنستين النساء مستأصلات الرحم }
\end{aligned}
$$

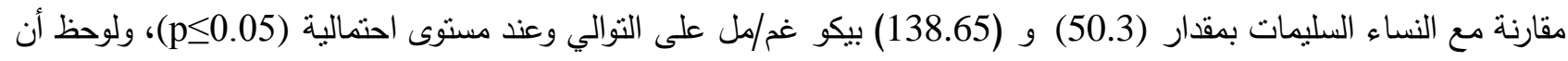

$$
\begin{aligned}
& \text { هناك ارتفاعاً معنوياً في مستوى الفرتين عند النساء مستأصلات الرحم مقارنة بالنساء السليمات بمقدار (64.35) و (52.10) ملغم/ }
\end{aligned}
$$

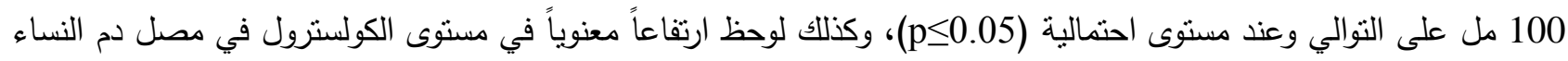

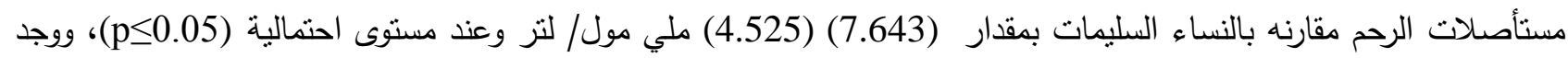

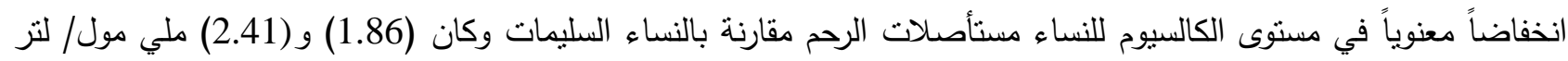

$$
\begin{aligned}
& \text { على التوالي عند مستوى احتمالية (P<0.05). بينما أظهرت النتائج ارتفاعاً طفيفاً في مستوى الفسفور مقارنة بالنساء السليمات } \\
& \text { وكان (3.95) و (3.73) ملي مول/ لتر على النوالي. } \\
& \text { الكلمات الدالة: هرمون الاستروجين، الفريتين، الكولسترول، الكالسيوم، الفسفور. }
\end{aligned}
$$




\section{INTRODUCTION}

Hysterectomy is a surgical procedure to remove the uterus, ovaries, fallopian tubes (Singh et al., 2015). Hysterectomy may involve the entire removal of the uterus (fundus and cervix), whereas partial removal of the uterine body includes leaving the cervix intact and thus it is called supracervical (Wright et al., 2013; Sardeshpande Nilangi, 2015). Estrogen is one of the sexual hormones that is produced in the ovaries, and promotes the development and maintenance of female characteristics in the human body (BaldaçaraI and Silva, 2017). It plays an essential role in the growth and development of female secondary sexual characteristics, such as breasts, pubic and armpit hair in addition to the regulation of the menstrual cycle and the reproductive system. Estrogen are adrenal glands and fat tissues that work together with calcium, vitamin D, and other hormones and minerals to build bones (Berent-Spillson et al., 2015).

Ferritin is an intra-cellular storage protein with high capacity to store more than 4000 iron atoms. The concentration of ferritin in serum correlates well with the amount of storage iron as proven by phlebotomy trials. Hence, serum ferritin is a good indicator of the body's total iron stored (Frazer and Anderson, 2014). In human, iron is an essential component of proteins involved in oxygen transport, and it is essential for the regulation of cell growth and differentiation too (Kujawska et al., 2016).

Cholesterol is a waxy fat-like substance that is found in all the cells of the human body. The human body needs some amounts of cholesterol to make hormones, vitamin D3, and substances that help the body to digest its food. and the body can make all the cholesterol it needs (Sheehan and Kathleen , 2012).

Phosphorus is essential to all forms of life, because it is a key element in many physiological and biochemical processes. It can be found in every cell present in all living organisms. Phosphorus is indispensable and cannot be replaced by any other element. Phosphorus occurs in complex DNA and RNA structures which hold and translate genetic information, and thus controls all living processes in plants, animals and human (Sheehan and Kathleen, 2012; Uribarri and Calvo, 2014).

The aim of this study is to find out effect of Estrogen hormone, ferritin, cholesterol, calcium and Phosphorus on women who have undergone uterine removal, as well as to know the effect of the removal period on the abovementioned parameters.

\section{Sample Used}

\section{MATERIAL AND METHODS}

Control group: blood serum was obtained from (40) healthy control women ranging in their age between (38-70).

Patients group: blood serum was obtained from (40) women who have undergone uterine removal, and their ages also ranged between (38-70) years. The blood samples were collected from women without using the tunica, and placed in dry tubes. The tubes were then immersed in a water bath of $37^{\circ} \mathrm{C}$ temperature for 15 minutes. Later on, the collected part of the solution was separated using a centrifuge at $4000 \mathrm{rpm}$ for 10 minutes to obtain a clear solution which represents the serum (Frances, 2000). These samples were collected from Al-Kansaa Hospital and the collection period and complication of work was one year.

\section{Estimation of The Biochemical Parameters in Serum}

The estrogen hormone in serum was analyzed through enzymatic methods using Tosoh AIA 360, a Japanese hormonal system (Goisk et al., 1986). Ferritin protein in the serum was also analyzed through enzymatic methods using Tosoh AIA 360, Japanese hormonal system (Clichton, 1971). Total serum cholesterol was determined by an enzymatic method using a standard kit manufactured by Biocon (Germany) (Burtis and Ashwood, 1999). Calcium and Inorganic phosphorus concentration in serum were estimated colorimetrically using akit manufactured by Biolabo (France), (Burtis and Ashwood, 1999). 


\section{Statistical Analysis}

The results were statistically analyzed in the following methods:

Standard Statistical Methods: to determine the average and standard deviation rate.

T-Test by using the SPSS program: to compare two variables and find the differences between the values that emerged from the value of $\mathrm{P}$ which were considered $(\mathrm{P} \leq 0.05)$ significant and $(\mathrm{P}>0.05)$ no significant.

\section{RESULTS AND DESCUSSION}

Table (1) the results of the measured biochemical parameters investigated in the present study, Table (2).

Table 1: Comparison between the control group and the patients group for all measured parameters

\begin{tabular}{|l|l|l|}
\hline \multirow{2}{*}{ Parameters } & Mean \pm SD \\
\cline { 2 - 3 } Estrogen hormone $(\mathrm{Pg} / \mathrm{ml})$ & $138.65 \pm 55.58$ & $50.3 \pm 14.68^{\star \star \star}$ \\
\hline Ferritin(mg/dl) & $52.10 \pm 14.4$ & $64.35 \pm 14.6^{\star \star}$ \\
\hline Cholesterol(mmole/L) & $4.53 \pm 0.91$ & $7.64 \pm 1.39^{* * *}$ \\
\hline Calcium(mmole/L) & $2.41 \pm 0.236$ & $1.86 \pm 0.315^{* * *}$ \\
\hline Phosphorus (mmole/L) & $3.73 \pm 0.68$ & $3.95 \pm 0.487^{*}$ \\
\hline
\end{tabular}

Values are the mean \pm SD,P values of women who have undergone uterine removal in comparison with control $* \leq 0.05$ : no significance, $* * \leq 0.05$ : significant difference $* * * 0.05$ :highly significant difference.

Table 2: Comparison between the patients group according to the period of uterus removal for all measured parameters

\begin{tabular}{|c|c|c|}
\hline Parameters & Mean \pm SD of patients group according to the years of uterus removal \\
\hline & $\mathbf{( 4 - 9 )}$ Year & $\geq \mathbf{1 0}$ year \\
\hline Estrogen hormone $(\mathrm{Pg} / \mathrm{ml})$ & $54.21 \pm 16.27$ & $44.94 \pm 10.01 * * *$ \\
\hline Ferritin $(\mathrm{mg} / \mathrm{dl})$ & $67.87 \pm 12.45$ & $58.5 \pm 17.37 * *$ \\
\hline Cholesterol(mmole/L) & $7.04 \pm 0.56$ & $8.84 \pm 1.8^{* * *}$ \\
\hline Calcium $(\mathrm{mmole} / \mathrm{L})$ & $1.94 \pm 0.33$ & $1.7 \pm 0.23^{* * *}$ \\
\hline Phosphorus $(\mathrm{mmole} / \mathrm{L})$ & $3.91 \pm 0.62$ & $4.01 \pm 0.26^{*}$ \\
\hline
\end{tabular}

Values are the mean $\pm \mathrm{SD}, \mathrm{P}$ values of patients group according to period of uterus removal compared with control $* \leq 0.05$ : no significant, $* * \leq 0.05$ : significant difference $* * * \leq 0.05$ :highly significant difference..

\section{Serum Estrogen Hormone}

The results in (Table 1) show a significant decrease in the estrogen hormone level in the serum of women with hysterectomy when compared with control group $(50.3 \pm 14.68) \mathrm{Pg} / \mathrm{ml}$, $(138.65 \pm 55.58) \mathrm{Pg} / \mathrm{ml}$ respectively at $(\mathrm{p} \leq 0.05)$ after removal of the uterus with the ovaries which isin charge of hormone production. These operations result in hormonal imbalance inside the woman's body, and thus leads to a significant reduction in the secretion of the estrogen hormone which is responsible for controlling various chemical processes (Wu et al., 2007; Van der Voort et al., 2001). Other causes that may decrease production of the estrogen and progesterone hormones, a surgery that removes both ovaries or some types of chemotherapy. From a physiological point of view, menopause happens as the consequence of reduction in the ovaries' 
production of estrogen and progesterone hormones (Laughlin et al., 2000). The researchers also found a relationship between estrogen hormone and uterine cancer (Ahmad and Ali, 2007).

The investigation also studied the influence of the period in the removal of the uterus on estrogen hormones. On this account, we divided patients into two groups, the first group includes women who have undergone uterus removal within a period less than 10 years (4-9), whereas the involved women who have undergone uterus removal within a period up to 10 years (10-20). As shown in (Table 2) disclosed that the level of estrogen hormone in the second group has significantly decreased when compared with that of the first group due to the level of estrogen hormone affected by removal period. These results were in good agreement with those obtained by other investigators (Bodner-Adler et al., 2014). Another possible reason for these findings may be due to the fact that the pituitary gland is considered as a second messenger, giving instructions to produce the estrogen (Hamilton et al., 2014; Emerald et al., 2016).

\section{Ferritin Level in Blood Serum}

Table (1) shows a significant increase in ferritin level for the patients group at $(p \leq 0.05)$ when compared with the control group. This increase in the ferritin level often happens after surgery (Van Iperen, 1998), due to the lack of a major mechanism of iron excretion (Milman and Kirchhoff, 1992). Moreover, the results listed in (Table 2) refered to a significant difference inferritin level in the second group $(>10$ years) of the uterus removal at $(\mathrm{p} \leq 0.05)$ when compared with the first group ( $\leq 10$ years) (Touitou, 1985). Since trans-ferritin protein is responsible for transferring iron from the bloodstream to body cells, which is necessary, a decrease in this protein level leads to an elevation of iron level in the blood (Himmelfarb et al., 2016; Abramowskia et al., 2014). In the second group, biological defect in the process of iron secretion and output was greater than those of the first group. Excess of iron stimulation resulted in the formation of more free radicals, hydroxy, the most destructive free radicals known to scientists in the human body which can destroy DNA, proteins and it can transfer electrons in mitochondria and cellular membranes (Jomova and Valko., 2011; Dev and Babitt., 2017).

\section{Serum Cholesterol Level}

The result have shown a significant increase in the cholesterol level in women serum with a hysterectomy when compared with control $(7.64 \pm 1.39) \mathrm{mmole} / \mathrm{L},(4.53) \mathrm{mmole} / \mathrm{L}$ respectively at ( $\mathrm{p} \leq 0.05)$, this is identical with (Yazdani et al., 2014; Matthews et al., 2009). The obtained findings are consistent with a hypothesis that lovastatin increases activity of HMG-CoA reeducates which is in charge of cholesterol synthesis, biliary lipid secretion, and elevated blood cholesterol through a feedback mechanism (Fukao et al., 2014).In the present study, the total cholesterol levels were significantly increased in women who have undergone a surgery. These findings are in agreement with those given by other researchers (Igweh et al., 2005). Other researcher also found that the relationship of cholesterol to uterine cancer was direct (Allwsh, 2002). Changes that occur in the lipid profile after menopause are associated with increasing risk of atherosclerosis, coronary heart disease and myocardial infarction, as a result in the lack of estrogen. Ovarian estrogen is inversely related to the development of cardiovascular disease and elevated serum lipid levels (Ismet et al., 2010; Gavin et al., 2012).

\section{Calcium Level in Blood Serum}

The results in (Table 1) show a significant decrease in calcium level in serum of women who have undergone uterine removal (1.86) $\mathrm{mmol} / \mathrm{L}$ when compared with control (2.41) $\mathrm{mmol} / \mathrm{Lat}$ $(\mathrm{p} \leq 0.05)$. Hypocalcaemia was observed in hysterectomy patients due to the estrogen concentration which is reduced after the removal of the uterus. Estrogen has a modulator effect on the calcium metabolism. It is also responsible for the penetration of calcium into the bone matrix. A decrease in the levels of estrogen after hysterectomy can cause an excessive loss of calcium, leading to osteoporosis. An additionally increasing risk for bone fracture was observed in the post hysterectomy patients (Van der voort et al., 2001; Sreekantha et al., 2011). The present study also investigates effect of the period of the uterus removal on calcium levels as presented in (Table 2) 
which showed a significant decrease in calcium level in the second group when compared to the first group (Prabha et al., 2015; Yeldose et al., 2015).

\section{Phosphorus Level in Blood Serum}

Table (1) shows a slight increase in phosphorus level in the women who have undergone uterine removal when compared with healthy women (3.95) mmole/ L and (3.731) mmole/ L, respectively. Table (2) also depicts a simple significant differences between the first group and second group (Calvo and Uribarri, 2013). This increase in phosphorus may be due to hormonal imbalance after the hysterectomy (Suwansakri et al., 2005).

\section{CONCLUSIONS}

According to the obtained results, it was found that a significant decrease in the estrogen hormone level in women who have undergone uterine removal, while a significant increase in the levels of ferritin as well as cholesterol. The study also indicated a slight increase in the phosphorus level. The study of the period of uterine removal on those parameters was also investigated and the results exhibited a decrease in the levels of estrogen hormone and calcium in the second group in comparison to those of the first group. Levels of cholesterol and phosphorus in the second group were raised in comparison with the first group, while level of ferritin was increased in the first group in comparison to the second group.

\section{REFERENCES}

Abramowskia, S.W.; Waeberb, G.; Gassnerc, C.; Buserd, A.; Freyc, B. M. (2014). Physiology of iron metabolism. Transfusion Med. Hemo., 41(3),213-221.

Ahmad, T.Y.; Ali, W.K. (2007). Some biochemical parameters in breast cancer. Raf. J. Sci., 18(2), 4657.

Allwsh, T.A. (2002). Study of the relation between selenium and different types of lipids in cancer patients. Raf. J. Sci., 13(1), 40-47.

BaldaçaraI, C.; Silva, I. (2017). Association between asthma and female sex hormones Sao Paulo. Med J., 135(1), 4-14.

Berent-Spillson, A.; Briceno, F.; Pinsky, A.; Simmen, A.; Persad, C.C.; Zubieta, J.K.; Smith, Y.R. (2015). Distinct cognitive effects of estrogen and progesterone in menopausal women. Psychoneuro Endocrinology, 59, 25-36.

Bodner-Adler, B.; Bodner, K.; Kimberger, O.; Halpern, K.; Rieken, M.; Koelbl, H.; Umek, W. (2014). Role of serum steroid hormones in women with stress urinary incontinence a case-control study. BJU Int., 120(3), 416-421.

Burtis, C.A.; Ashwood, E.R. (1999). "Tietz N.W. Text Book of Clinical Chemistry". $3^{\text {rd }}$ ed. W.B, Saunders Company, U.S.A., pp.1395-1439, 490, 4821406-1457.

Calvo, M.S.; Uribarri, J. (2013). Public health impact of dietary phosphorus excess on bone and cardiovascular health in the general population. Am. J. Clin. Nutr., 98, 6-15.

Clichton, R.R. (1971). Ferritin structure, synthesis and function. New Eng. J. Med., 284, 1413.

Dev, S.; Babitt, J.L. (2017). Overview of iron metabolism in health and disease. Hemodialysis International, 21, 6-20.

Emerald, M.; Caballero, B.; Finglas, P.; Toldra, F. (2016). Pituitary gland and hormones. Encyclopedia of food and health. Phytoceuticals International, 4, 392-400.

Frances, T. (2000). "A Manual of Laboratory and Diagnostic Test". 6 ${ }^{\text {th }}$ ed., J.B. Lippincott Com., U.S.A., pp. 34,688.

Frazer, D.M.; Anderson, G.J. (2014). The regulation of iron transport. Bio. Factors, 357, 206-214.

Fukao, T.; Mitchell , G.; Sass, J.O.; Hori, T.; Orii, K.; Aoyama, Y. (2014). Ketone body metabolism and its defects. J. Inherit. Metab. Dis., 37, 541-551. 
Gavin, K.M.; Jankowski, C.; Kohrt, W.M.; Stauffer, B.L.; Seals, D.R.; Moreau, K.L. (2012). "Hysterectomy Associated with Large Artery Stiffening in Estrogen Deficient Postmenopausal Women". Menopause N.Y., pp. 1000-1007.

Goisk, J.; Welshons, W.V.; Sakai , D.; Hansen, J.; Walent, I.; Kassis, J.; Shull, J.; Stack, G.; Campen, C. (1986). Evolution of a model of estrogen action. Recent Prog. Horm. Res., 42, 297-329.

Hamilton, K.J.; Arao, Y.; Korach , K. (2014). Pituitary gland. Estrogen hormone Biol., 14, 3-8.

Himmelfarb, J.; Vaziri, N.D.; Fishbane, S.; Rostoker, N. (2016). Iron regulation. J. Am. Soc., 18(2), 379-381.

Igweh, J.C.; Nwagha, I.U.; Okaro, J.M. (2005). The effects of menopause on the serum lipid profile of normal females. Nigerian J. Physiol. Sci., 20(1-2), 48-53.

Ismet, T.A.; Tuna, V., Alkis, I.; Safiye, A.S.; Imamoglu, N. (2010). Variations in blood, Bayram lipid profile thrombotic system, arterial elasticity psychosexual parameters in the cases of surgical and natural menopause. Australian and New Zealand J. Obstetrics and Gynaecol., 50, 194-199.

Jomova, K.; Valko, M. (2011). Advances in metal-induced for oxidative stress and human disease. Toxicol., 65, 283-287.

Kujawska, M.; Ewertowska, M.; Ignatowicz, E.; Szaefer, H. (2016). Evaluation of safety of iron fortified, soybean spronts a potential components of functional food in rat. Toxicol. Med. Sci., 30,631-660.

Laughlin, G.A.; Barrett-Connor, E.; Kritz-Silverstein, D.; Von Muhlen, D. (2000). Hysterectomy, oophorectomy, and endogenous sex hormone levels in older women: the Rancho Bernardo Study. J. Clin. Endocrinol. Metab., 85(2), 645-51.

Matthews, K.A.; Crawford, S.L.; Chae, C.U. (2009). Changes in cardiovascular disease risk factors in midlife women. J. Am. Coll. Cardiol., 54, 2366-2373.

Milman, N.; Kirchhoff, M. (1992). Iron stores in women: evaluation by serum ferritin and hemoglobin. Ann. Hematol., 63,103-135.

Prabha, Y.S.; Ashalata, K.; Babu, S.V.; Kumari, P.K.; Nagamani, M. (2015). A study of bone markers serum calcium, serum phosphorus and serum alkaline phosphates in post menopausal women in east godavari district. Andhra Pradesh, India., 14(6), 1-3.

Sardeshpande Nilangi, N. (2015). Hysterectomy among premenopausal women and its' impact on their life findings from a study in rural parts of India. International Research J. Soc. Sci., 4(4), 15-22.

Sheehan, J. ; Kathleen, N. (2012). "Cholesterol and Hearth Health". J. American Sci. 7(2), 6-7.

Singh, A.; Naik, S.; Mahilange, A. (2015). Hysterectomy, changing trends in a tertiary care center. $J$. Evolution Med. and Dental Sci., 4(89), 15407-15409.

Sreekantha Satisha, T.G.; Avinash, S.S.; Manjunatha Goud, B.K.; Remya Sudhakar, G.K.; Rangaswamy, R.; Raghavendra, V.T. (2011). Magnesium and calcium levels in early surgical menopause. J. Cli. and Diagnostic Research, 5(1), 55-57.

Suwansakri, J.; Vattanawaha, A.; Wiwanitkit, V. (2005). Serum magnesium level in diabetic and osteoporosis risk at female subjects. J. Lab. Med., 1(1), 1-4.

Touitou, Y. (1985). Plasma ferritin in old age Influence of biological and pathological factors in a large elderly population. Clinica. Chimica. Acta., 149, 37-45.

Uribarri, J.; Calvo, M.S. (2014). Dietary phosphorus intake and health. Am. J. Clin. Nutr., 99, 247-8. Printed in USA American Society for Nutrition.

Van der Voort, D.J.; Geusens, P.P.; Dinant, G.J. (2001). Risk factors for osteoporosis related to their outcome fractures. Osteoporosis International, 12(8), 630-638.

Van Iperen, C.E. (1998). Iron metabolism and erythropoiesis after surgery. British J. Surgery, 85, 41-45.

Wright, J.D.; Herzog, T.J.; Tsui, J.; Ananth, C.V.; Lewin, S.N.; Lu, Y.S. (2013). Nationwide trends in the performance of inpatient hysterectomy in the united states. Obstet. Gynecol., 122(2), 233-241.

Wu, J.M.; Wechter, M.E.; Geller, E.J.; Nguyen, T.V.; Visco, A.G. (2007). Hysterectomy rates in the United States. Obstet. Gynecol., 110(5), 1091-1095.

Yazdani, S.; Sharbatdaran, M.; Samakoosh, M.A.; Bouzari, Z.; Masoudi Caspian, Z. (2014). Glucose Tolerance and lipid profile changes after surgical menopause. J. Intern. Med., 5(2), 114-117.

Yeldose, S.; Avinash, S.S.; Sreekantha, A.; Kumar, K.; Malathi, M.; Shivashankara, A.R. (2015). Altered levels of serum and urinary calcium, phosphate and magnesium in natural menopausal versus surgical menopausal south Indian women. International J. Clin. Biochem. and Research, 2(3), $177-181$. 